Preprint of Kern, Z., Harmon, R.S., Fórizs, I. (2016) Stable isotope signatures of seasonal precipitation on the Pacific coast of central Panama. Isotopes in Environmental and Health Studies 52: 128-140. doi: 10.1080/10256016.2015.1016021

\title{
Stable Isotope Signatures of Seasonal Precipitation on the Pacific Coast of Central Panama
}

\author{
Zoltán Kern ${ }^{1}$, Russell S. Harmon ${ }^{2,3^{*}}$, István Fórizs ${ }^{1}$ \\ ${ }^{1}$ Institute for Geological and Geochemical Research, Research Centre for Astronomy and Earth \\ Sciences, Hungarian Academy of Sciences, Budapest, Hungary \\ ${ }^{2}$ USACE Engineer Research \& Development Center International Research Office, Ruislip, UK \\ ${ }^{3}$ Department of Marine, Earth, \& Atmospheric Sciences, North Carolina State University, USA \\ * corresponding author
}

\begin{abstract}
As calculated from IAEA-WMO GNIP archived data, the amount-weighted local meteoric water line for the Pacific coast of central Panama is: $\delta^{2} \mathrm{H}=7.63( \pm 0.08) \times \delta^{18} \mathrm{O}+6.51( \pm 0.49)$. Amount-weighted mean isotopic values were regressed against the sea surface temperature (SST) fields of the adjacent tropical oceans. A negative correlation of precipitation isotope composition with Caribbean SSTs is only observed for the early wet season (May-June), whilst the mid-summer dry period is characterized by positive correlation with eastern Pacific SSTs, similar to the late wet season (Oct-Nov). The negative response of May-June rainfall isotopic composition to Caribbean SSTs is explained by a SST-mediated change in stratiform rain fraction from organized convective systems proximal to the ITCZ. The positive correlation for the rest of the wet season, when the organized convective zone of ITCZ and its attached stratiform belt are distant from the Pacific coast of Panama, is interpreted as simple evaporative temperature effect on isotopic fractionation.
\end{abstract}

Keywords: Panama, stable isotopes, meteoric water line, tropical hydrometeorology, amount effect, ITCZ

\section{Introduction}

The formation of the Isthmus of Panama around 3 million years ago [1] resulted in the cessation of direct water exchange between the Atlantic and Pacific Ocean basins, which substantively influenced global climate by strengthening the Gulf Stream and enhancing thermohaline circulation in the North Atlantic [2,3]. Since the closure of the Panama seaway, water exchange between Atlantic and Pacific Oceans has been restricted predominantly to transisthmian atmospheric moisture flux and surface run-off to a lesser degree. 
Preprint of Kern, Z., Harmon, R.S., Fórizs, I. (2016) Stable isotope signatures of seasonal precipitation on the Pacific coast of central Panama. Isotopes in Environmental and Health Studies 52: 128-140. doi: 10.1080/10256016.2015.1016021

The Atlantic-Pacific moisture flux deserves special attention because it has a prominent role in maintaining relatively high salinities within the subtropical Atlantic and it acts as an important driving force for global oceanic thermohaline circulation [e.g. 4, 5]. Even small changes in the transfer of freshwater across the Isthmus of Panama associated with different climate regimes could affect the salt balance between the Atlantic and Pacific Oceans and, consequently, influence global deep-ocean circulation, including the possible shutdown of North Atlantic Deep Water formation [4-6]. Improving current understanding of past changes in moisture transport across Central America is a great challenge for paleoscience, motivating both marine [7] and terrestrial [8] paleoproxy studies. An understanding of the recent hydrological cycle in stable isotopic terms [e.g. 9, 10], however, requires the detailed characterization of precipitation. Such information is a crucial prerequisite for evaluating the inter-ocean moisture fluxes related to both the terrestrial (i.e. riverine) and the atmospheric branches of the regional hydrological cycle.

According to the classical interpretation, both monthly and annual $\delta^{2} \mathrm{H}$ and $\delta^{18} \mathrm{O}$ ratios at any place tend to be inversely correlated with rainfall amount because of Rayleigh distillation processes within a cloud during raindrop creation and evolution [11]. Such an 'amount-effect' was considered by [12] and [9] to be the dominant mechanism governing the isotopic composition of precipitation in Panama. However, it has been observed recently that short-term (daily or event-based) isotopic variations can be independent of local precipitation intensity, even at marine island stations [13], suggesting that there may be a more complex process mechanism determining the apparent anticorrelation between rainfall amount and its stable isotope composition. Also, a 'source-effect', referring to the conditions at the source of water vapor bringing precipitation to the given site, may play an important role in determining the isotopic composition of tropical rainfall during the dry season [14]. Thus, further examination of the stable isotopic character and seasonal variations in the moist humid tropics is warranted.

This study utilizes a dataset of 245 monthly $\delta^{2} \mathrm{H}$ and $259 \delta^{18} \mathrm{O}$ values, including 233 pairs, from a merged set of data from two nearby stations located on the Pacific coast of Panama at which precipitation was collected and analysed between 1968 and 2006 as a part of the IAEAWMO Global Network of Isotopes in Precipitation (GNIP) program. This extended dataset provides the basis for a new analysis and revised characterization of the primary and secondary water isotopic features, the local meteoric water line, and further consideration of the forcing mechanisms governing the $\mathrm{H}$ - and $\mathrm{O}$-isotope systematics of the precipitation on the Pacific coast of Panama at a seasonal scale.

\section{Hydrometeorology}

The hydrometeorology of Panama is particularly well understood as a consequence of more than a century of rainfall-runoff measurements that date back to the French effort to construct a sea-level canal in the late $19^{\text {th }}$ century. With a moist humid climate, temperatures across Panama 
Preprint of Kern, Z., Harmon, R.S., Fórizs, I. (2016) Stable isotope signatures of seasonal precipitation on the Pacific coast of central Panama. Isotopes in Environmental and Health Studies 52: 128-140. doi: 10.1080/10256016.2015.1016021

are uniformly high, with little diurnal and seasonal variation. Our study sites near the Pacific coast of central Panama adjacent to the Pacific terminus of the Panama Canal has an average annual temperature of $27^{\circ} \mathrm{C}$ and mean total rainfall of $1760 \mathrm{~mm}$ [15]. Because of its geospatial situation as a narrow isthmus bordering both the Atlantic and Pacific Oceans, rainfall in the study area can be derived either from atmospheric moisture in the Caribbean that is transported across Panama by northerly and northeasterly winds prevailing during most of the year or by southwesterly winds off the Pacific occurring during late autumn. However, the moisture that departs from the Pacific source region is not able to reach the entire Central American region, contributing only to precipitation along the southernmost portion of the Pacific coast including Panama [16].

Atmospheric circulation over the southern Caribbean region is controlled by the confluence of the NE and SE trade winds at the Inter Tropical Convergence Zone (ITCZ), a band of low pressure at the boundary of northern and southern tropical Hadley cells that gird the planet. The movement of the ITCZ is the dominant driver of seasonality across the isthmus of southern Central America as well as the major determinant of the timing and distribution of precipitation. As a consequence, Panama experiences pronounced wet and dry seasons [17]. ITCZ movement follows the global insolation maximum, but lagged by approximately a month. Between December and April, the ITCZ is located south of the Panamanian isthmus in the Pacific Ocean (Fig. 1), resulting in decreased cloud cover, increased temperature and a significant reduction in precipitation across the southern side of the country. Between April and December, the Panamanian wet season, the ITCZ lies at or slightly north of Panama, bringing increased cloud cover and precipitation. From January through March, the ITCZ passes southward across the isthmus to a position to the south of the country bringing a predominant influence by the northeast trade winds. During this January to April season, what little precipitation falls is produced by tropical atmospheric systems that move southwards across Panama from the Caribbean. During this time, near-surface relative humidity drops to $\sim 70 \%$ in the Panama Canal region which is the focus of this study [18]. Subsequently, the ITCZ migrates north back across Panama bringing the May to December rainy season. A secondary dry season frequently appears along the Pacific coast as the rainfall decreases between July and August. The intensity of this midsummer drought shows large inter-annual variability [19]. By the end of August, beginning of September, rainfall again increases as the ITCZ starts moving south. A strong sea-surface temperature (SST) gradient across the equator enhances a low-level westerly jet (the western Colombian Jet) that transports large amounts of Pacific moisture into the Panama Bight region [20]. This jet attains the maximum core wind velocities during October-November generating the second rainfall maximum along the Pacific coastal Panama [21].

While the N-S motion of ITCZ is the dominant factor affecting rainfall across Panama, there are other influences. Eastward moving tropical waves are common [22]. The Coriolis force near 
Preprint of Kern, Z., Harmon, R.S., Fórizs, I. (2016) Stable isotope signatures of seasonal precipitation on the Pacific coast of central Panama. Isotopes in Environmental and Health Studies 52: 128-140. doi: 10.1080/10256016.2015.1016021

the latitude of Panama is so small that tropical cyclones are not sustained. In the entire hydrometeorological record from Panama, only one tropical cyclone has made landfall, Hurricane Martha in 1969, but infrequently tropical cyclones will have some impact on Panama in terms of rainfall. Occasionally extratropical cold fronts will propagate as far south as Panama in the boreal winter [23] and interact with eastward moving tropical waves, frequently producing large rainfall events from December to February that can have significant geomorphic impacts.

Rainfall across Panama varies regionally from less than 1300 to nearly $7000 \mathrm{~mm} / \mathrm{y}$ [24, 25]. Precipitation is strongly seasonal, with pronounced wet and dry seasons. The presence of the Cordillera Central, a central spine of mountain ranges that rises up to $3000 \mathrm{~m}$ elevation, is an E$\mathrm{W}$ trending topographic barrier that creates a strong climate gradient from north to south across Panama. Since rain falls throughout the year along the Caribbean coast and wet season storms approach Panama from the north, annual rainfall accumulations here can be up to $7000 \mathrm{~mm} / \mathrm{y}$. The southern Pacific coast of central Panama, the Azuero peninsula, and portions of the Darién in eastern Panama receive the least rainfall $(<2000 \mathrm{~mm} / \mathrm{y})$ and consequently have a tropical dry and wet climate.

The primary source of inter-annual rainfall variability in Panama, as in much of Central America, is small SST differences between the Atlantic and Pacific Oceans [26, 27]. Oppositely signed SST anomalies in the Tropical North Atlantic Ocean and Tropical Pacific Ocean result in increased precipitation and wet-season duration $[28,29]$. When the Tropical North Atlantic Ocean is warm and conversely the Tropical Pacific Ocean is relatively cool, northeasterly trade winds are enhanced. During the wet season this leads to enhanced rainfall [26, 27]. Alexander et al. [30] have described how the conditions of the tropical Pacific Ocean, particularly as regards ENSO events, controls the SST state of the tropical Atlantic Ocean through a teleconnected atmospheric bridge. The La Niña and El Niño cycles of the Southern Oscillation (ENSO) occur about every five years in Panama and tend to result in respectively higher and lower rainfall and runoff than the annual average $[21,31]$. The comparatively low relief and the narrowness of the trans-isthmus region where the Panama Canal is located, permits complex interactions of moisture-laden winds associated with both Caribbean and Pacific atmospheric circulations [17]. The extent of interaction is not well constrained. For example, the Caribbean moisture flux has been estimated to be about $50 \%$ of the total freshwater income of the Eastern Pacific freshwater budget [32], whereas the Pacific moisture contribution for Pacific coastal regions at 22 to $64 \%$ [8]. Further study is needed to better constrain the large range of estimates for the degree of the Atlantic-Pacific moisture exchange. 
Table 1. Geographical basic data and summary statistics of the available archive water stable isotope data of Panama precipitation.

\begin{tabular}{|l|c|l|c|c|c|}
\hline \multicolumn{1}{|c|}{ Station } & Lat $\left({ }^{\circ} \mathrm{N}\right) /$ Lon $\left({ }^{\circ} \mathrm{W}\right)$ & Date of First \& Last Sample & $\delta^{2} \mathrm{H}$ & $\delta^{18} \mathrm{O}$ & $\mathrm{d}$-excess \\
\hline Howard Air Force Base & $8.920 / 79.600$ & Jul 1968/Nov 1997 & 217 & 231 & 205 \\
\hline University of Panama & $8.983 / 79.533$ & Sep 2002/ Feb 2006 & 28 & 28 & 28 \\
\hline
\end{tabular}

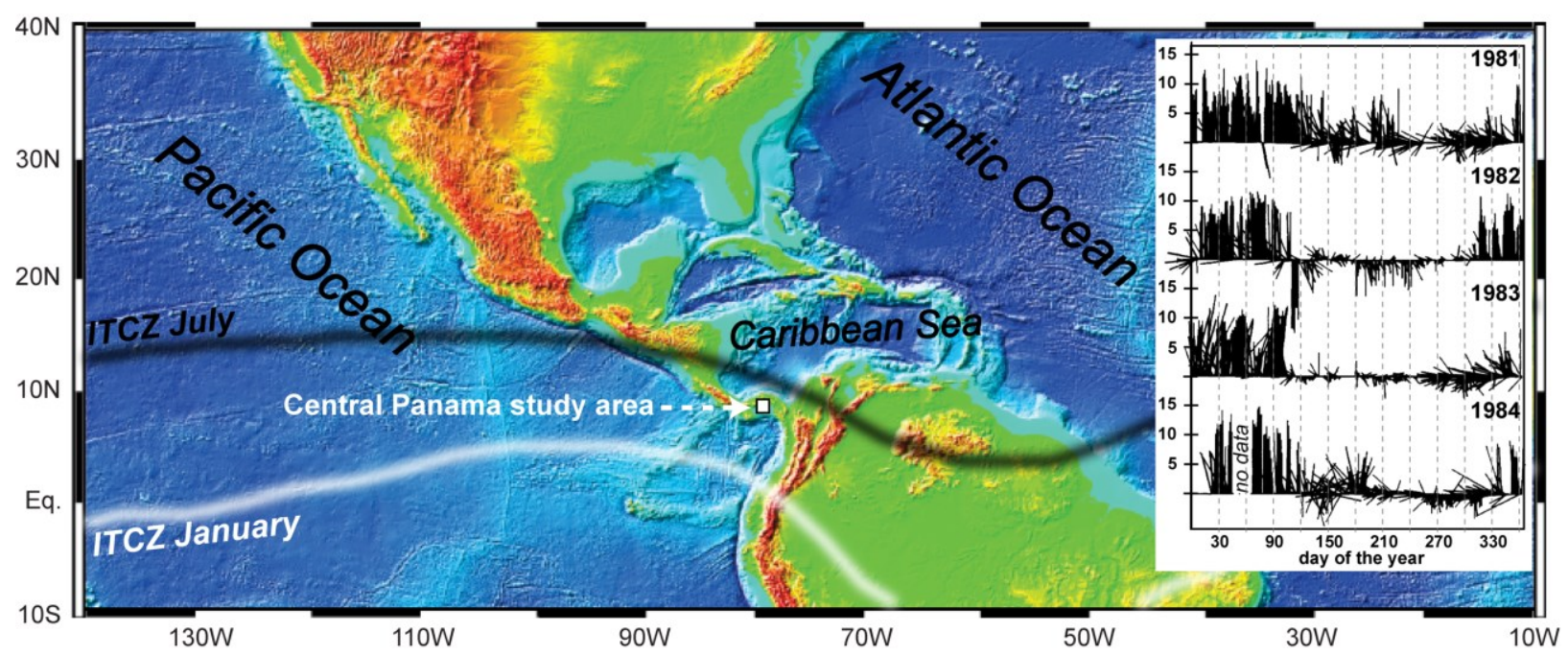

Figure 1. Topographic-bathymetric map (modified from ETOPO2v2 [38]) of the Central American region showing the seasonal maximum positions of the Intertropical Convergence Zone (ITCZ). The white square over central Panama denotes the area from $8.5^{\circ}$ to $9.5^{\circ} \mathrm{N}$ and from $80^{\circ}$ to $79^{\circ} \mathrm{W}$ corresponding to the Global Precipitation Climatology Centre grid box for the study area. Inset chart: Daily wind mean-vectors for Central Panama in the vicinity of the Panama Canal for 1981-84 redrawn after [18]. North winds are indicated by vectors extending straight up and south winds straight down, with vector length indicating the daily wind magnitude in $\mathrm{km} / \mathrm{h}$.

\section{Material and Methods}

\subsection{Stable isotope data}

The stable isotopic composition of a water, measured as the ratio between the abundance of heavy and light isotopes (such as ${ }^{2} \mathrm{H} /{ }^{1} \mathrm{H}$ and ${ }^{18} \mathrm{O} /{ }^{16} \mathrm{O}$ ) in the water molecule [33], is routinely used as a tracer in studies of the hydrological cycle at global, regional, and local scales (see e.g. [34]). In addition, many geological (e.g. [8]) and biological (e.g. [7]) materials can preserve the stable isotope signature of the paleo-water involved in their formation Their stable isotope analysis can provide a useful tool to characterize the past and present sources of meteoric precipitation that produce rainfall at a particular site and the dynamics of water transport in the atmosphere prior to a rainfall event. 
Preprint of Kern, Z., Harmon, R.S., Fórizs, I. (2016) Stable isotope signatures of seasonal precipitation on the Pacific coast of central Panama. Isotopes in Environmental and Health Studies 52: 128-140. doi: 10.1080/10256016.2015.1016021

Composite samples of monthly precipitation were collected and analysed for two stations on the Pacific coast of Panama (Fig. 1) - the University of Panama and the former Howard Air Force Base (Table 1). H- and O- isotope ratios were measured as a part of the International Atomic Energy Agency/World Meteorological Organization Global Network of Isotopes on Precipitation (GNIP) program [35]. The University of Panama site is situated in the San Miguelito district within the urban core of Panama City, whereas the site at the former U.S. Howard Air Force Base is located in a near-coastal area some $8 \mathrm{~km}$ to the southwest across the Panama Canal. Both sites lie approximately $1 \mathrm{~km}$ inland from the Pacific coast on the narrowest and lowest part of the Panamanian isthmus, some $50 \mathrm{~km}$ distant from Panama's Atlantic coast. The spatial distribution of surface water stable isotopic composition across the Panamanian isthmus, suggests that both Caribbean and Pacific moisture sources contribute to rainfall at these two GNIP stations $[9,32,36]$.

In this archived database [35], isotope abundances are expressed as per mil (\%) differences from the V-SMOW standard [37] using the $\delta$ notation, $\delta \mathrm{X}=\left[\left(\mathrm{R}_{\text {sample }} / \mathrm{R}_{\text {standard }}\right)-1\right] \times 1000$, where $\mathrm{X}$ is ${ }^{2} \mathrm{H}$ or ${ }^{18} \mathrm{O}$, $\mathrm{R}_{\text {sample }}$ is the sample ${ }^{2} \mathrm{H} /{ }^{1} \mathrm{H}$ or ${ }^{18} \mathrm{O} /{ }^{16} \mathrm{O}$ ratio, and $\mathrm{R}_{\text {standard }}$ is the ${ }^{2} \mathrm{H} /{ }^{1} \mathrm{H}$ or ${ }^{18} \mathrm{O} /{ }^{16} \mathrm{O}$ ratio of the standard. A secondary isotopic characteristic, the ' $\mathrm{d}$-excess', has been calculated as $\mathrm{d}$ $=\delta^{2} \mathrm{H}-8 \times \delta^{18} \mathrm{O}[11]$.

\subsection{Precipitation}

Reliable, non-biased precipitation data are crucial to calculate amount weighted multi-monthly mean isotopic values. The effectiveness of the precipitation record available from the GNIP is problematic because periodic gaps in its site records reduce the amount of usable isotope data. A previous study [10] completed the missing monthly values at Howard AFB using a nearby station record or by filling the gaps using the long-term monthly means.

For this study, we have utilized precipitation data from the Global Precipitation Climatology Centre (GPCC) Full Data Reanalysis [39], instead of the incomplete site records. The advantage of using this dataset compared to gap-filling from nearby stations, for instance, is that it is not only less prone to any single-station error because of its gridded character, but the local precipitation signal is most effectively emphasized so that it more appropriate for regional climate monitoring or water resources assessment studies. Support for this approach is provided by the Smithsonian Tropical Research Institute Agua Salud project [40], which observed a correlation length between $20-30 \mathrm{~km}$ for daily rainfall over Panama. Consequently, the grid spacing $\left(0.5^{\circ}, \sim 55 \mathrm{~km}\right)$ is within the correlation length for the monthly precipitation in this region.

The product GPCC contains the monthly totals on a regular grid of $0.5^{\circ} \times 0.5^{\circ}$, derived as precipitation anomalies at stations interpolated and then superimposed on the GPCC Climatology V2011 [41] in the corresponding resolution. Gridded values nearest to the two Panama GNIP 
Preprint of Kern, Z., Harmon, R.S., Fórizs, I. (2016) Stable isotope signatures of seasonal precipitation on the Pacific coast of central Panama. Isotopes in Environmental and Health Studies 52: 128-140. doi: 10.1080/10256016.2015.1016021

stations (Howard AFB and University of Panama) cover the $8.5-9.5^{\circ} \mathrm{N} ; \mathrm{W} 79-80^{\circ} \mathrm{N}$ domain (Fig. 1) were averaged and used as weights for further calculation. Monthly systematic gage measurement errors are available from January 2007 [42], the last year of the study period, which can be used to provide information on accuracy of and uncertainty in the rainfall estimates. Monthly relative systematic gage error in 2007 for the GPCC grid cell of Panama City range between 0.8 to $7.1 \%$. For, November and March, the estimates corresponded to $2.9 \mathrm{~mm}$ and $0.48 \mathrm{~mm}$, respectively.

\subsection{Statistical methods}

\subsubsection{Precipitation weighted local 'Meteoric Water Line'}

The linear relationship between $\delta^{2} \mathrm{H}$ and $\delta^{18} \mathrm{O}$ variations in precipitation observed globally was defined by [33] as the 'Meteoric Water Line' (MWL). An ordinary least-squares regression of $\mathrm{H}$ - and O-isotope ratios is the standard approach used to determine the MWL, which gives equal weight to all data points regardless of the precipitation amount they represent [43]. This standard approach was applied to the GNIP records for Panama by [9]), with the lower slope and y-intercept observed for the 'best-fit' line through the monthly data interpreted as evidence for isotopic enrichment of dry-season rainfall through evaporative effects.

An alternative approach has been developed for determining an appropriate local MWL for particular places based on a weighted precipitation methodology [44]. This approach to produce a precipitation-weighted local meteoric water line (PW-LMWL) is particularly appropriate for island and coastal sites, where precipitation with a low d-excess may result from first rainout or tropical storms and should thus result an improved estimate for isotope hydrological applications. This methodology, which accounts for the significant influence of rainfall amount, but also permits inclusion of data with a low d-excess, was used in this study.

\subsubsection{Seasonal isotope signals and their predictors}

Ocean-atmosphere phenomena manifested as sea surface temperature (SST) and circulation anomalies were observed to exert a control on precipitation $\delta^{18} \mathrm{O}$ values at the GNIP site at HAFB in central Panama [10]. In this study, the spatial signature of the two combined Panamanian water isotopic records on the SST field (HadlSST $1^{\circ} \times 1^{\circ}$ resolution; [45]) was tracked using tools available from KNMI Climate Explorer [46].

The sparse dry season precipitation across the Panama Canal region is prone to secondary evaporation because of the relatively low near-surface relative humidity [18]. Consequently, the evaporation-condensation signals of rainfall isotopic compositions can be heavily overprinted. Therefore, this study focuses on the wet season, when extensive amounts of rainfall occur during near-saturated atmospheric conditions down to the land surface. Note here that few wet season samples were also characterized by negative d-excess values which suggest partial evaporation 
Preprint of Kern, Z., Harmon, R.S., Fórizs, I. (2016) Stable isotope signatures of seasonal precipitation on the Pacific coast of central Panama. Isotopes in Environmental and Health Studies 52: 128-140. doi: 10.1080/10256016.2015.1016021

(most probably due to a sampling failure, for details see section 4.1.) so these samples were omitted from further analysis. Because of the dynamic changes in regional atmospheric circulation, spatial correlations were analysed for three bi-monthly core periods:

(i) May-June: The early summer time of peak rainfall;

(ii) July-August: The midsummer rainfall minimum, when the Caribbean atmospheric low-level jet reaches its maximum intensity providing the second peak of Atlantic-Pacific vapour transport [47];

(iii) October-November: The period of rainfall maximum, when the western Colombian atmospheric low-level jet transports large amounts of Pacific moisture into the Panama region [20].

This approach provides an insight of a finer temporal scale compared to an earlier study by Lachniet [10] that divided the entire wet season into halves.

\section{Results and Discussion}

\subsection{Stable Isotopes in Precipitation}

Respective ranges in $\mathrm{H}$ - and O-isotope composition for rainfall on the Pacific coast of central Panama are $\delta^{2} \mathrm{H}=-110.0$ to $+24.2 \%$ and $\delta^{18} \mathrm{O}=-15.29$ to $+3.59 \%$ (Fig. 2a). The seasonal structure of this record (Fig. 2b) is typical of tropical locations [48]. Annual maximum values ( $\sim 0 \%$ ) occur during the driest months in Panama (February-March), while the most depleted isotopic compositions are observed during the June rainfall maximum. The midsummer rainfall minimum (July-August) is characterized by less-depleted $\mathrm{H}$ - and O-isotope isotope ratios than those of the dry season. A second isotopic minimum in September precedes the absolute rainfall peak that culminates in late autumn (October-November). The secondary isotopic parameter, $\mathrm{d}$ excess, ranges between -9 and $16.8 \%$ without any significant seasonal structure. The interquartile range varies from $\sim 5$ to $10 \%$, but exhibits a large scatter of between $\sim-5$ to $15 \%$ within each month (Fig. 2c). There were 18 months with negative d-excess values. These negative values clearly point to secondary effects modifying the isotopic composition of precipitation in the given month (partial evaporation of the falling raindrops or partial evaporation of the collected water sample in the raingage). Partial evaporation of rain drops is quite likely during the sparse light rain events during the dry season. This process naturally and affects the dry season precipitation over the region so we have kept these data for the calculation of local meteoric waterline but with respect to this bias, the whole dry season was excluded from the spatial correlation analysis (see section 3.3.2). However it is virtually impossible to generate negative deuterium excess values during the wet season when $\mathrm{RH}$ is usually above $80 \%$. Therefore sampling failure or measurement error can be suspected for the rest 11 data and they were omitted from further calculations. 

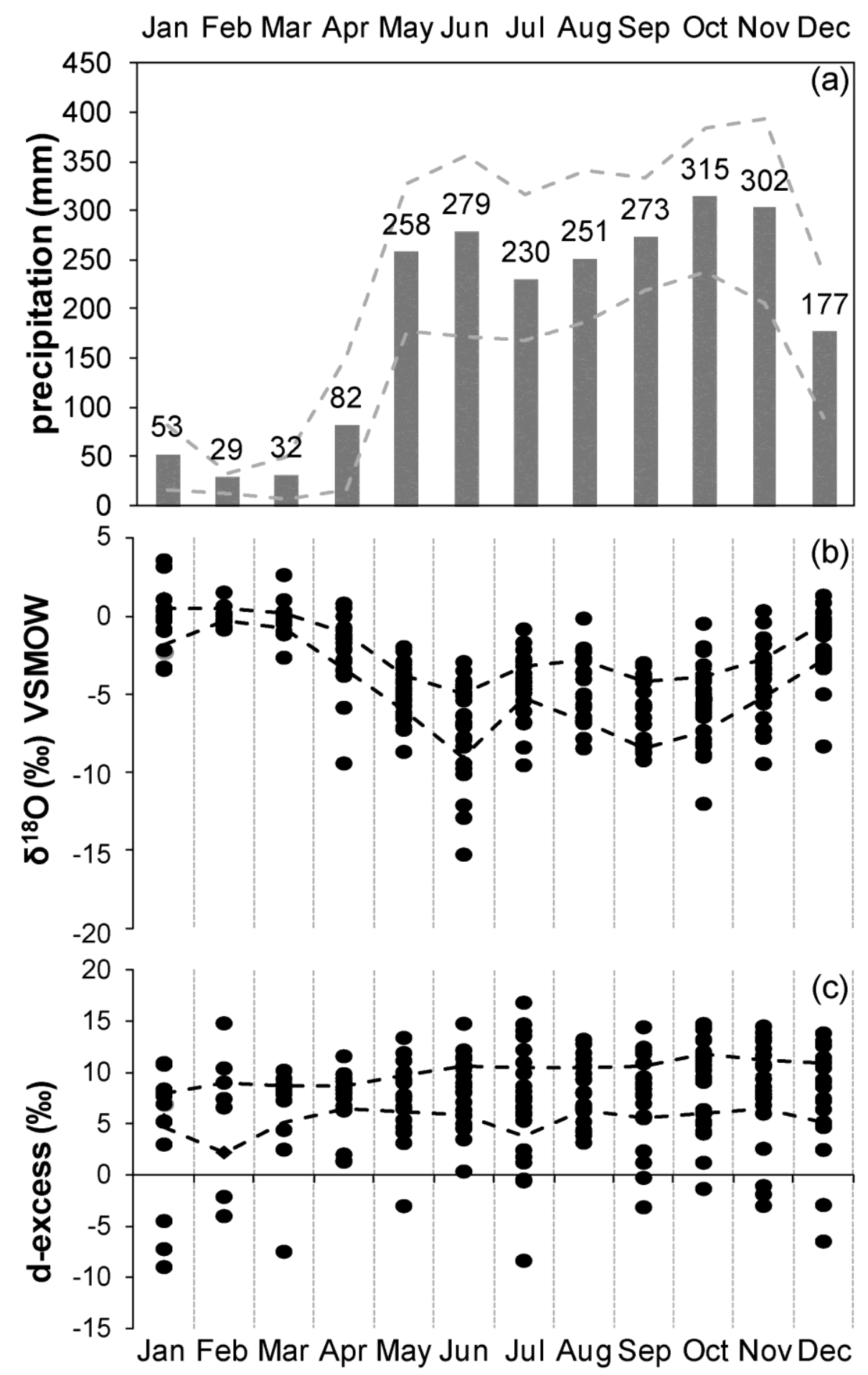

Figure 2. Rainfall seasonality for the Pacific coast of the Panama Bight for the 1968-2006 study period: (a) Long-term monthly mean precipitation (bars) and the upper/lower bound of the $66 \%$ probability range (dashed gray lines) obtained from the GPCC grid box shown in Fig. 1 (8.5-9.5 $\mathrm{N} ; 79-80^{\circ} \mathrm{W}$, with monthly means given above the corresponding bar; (b) Monthly distribution of the precipitation $\delta^{18} \mathrm{O}(\mathrm{n}=259)$ and $(\mathrm{c}) \mathrm{d}$-excess values $(\mathrm{n}=233)$. Dashed lines in both plots denote the interquartile ranges. 


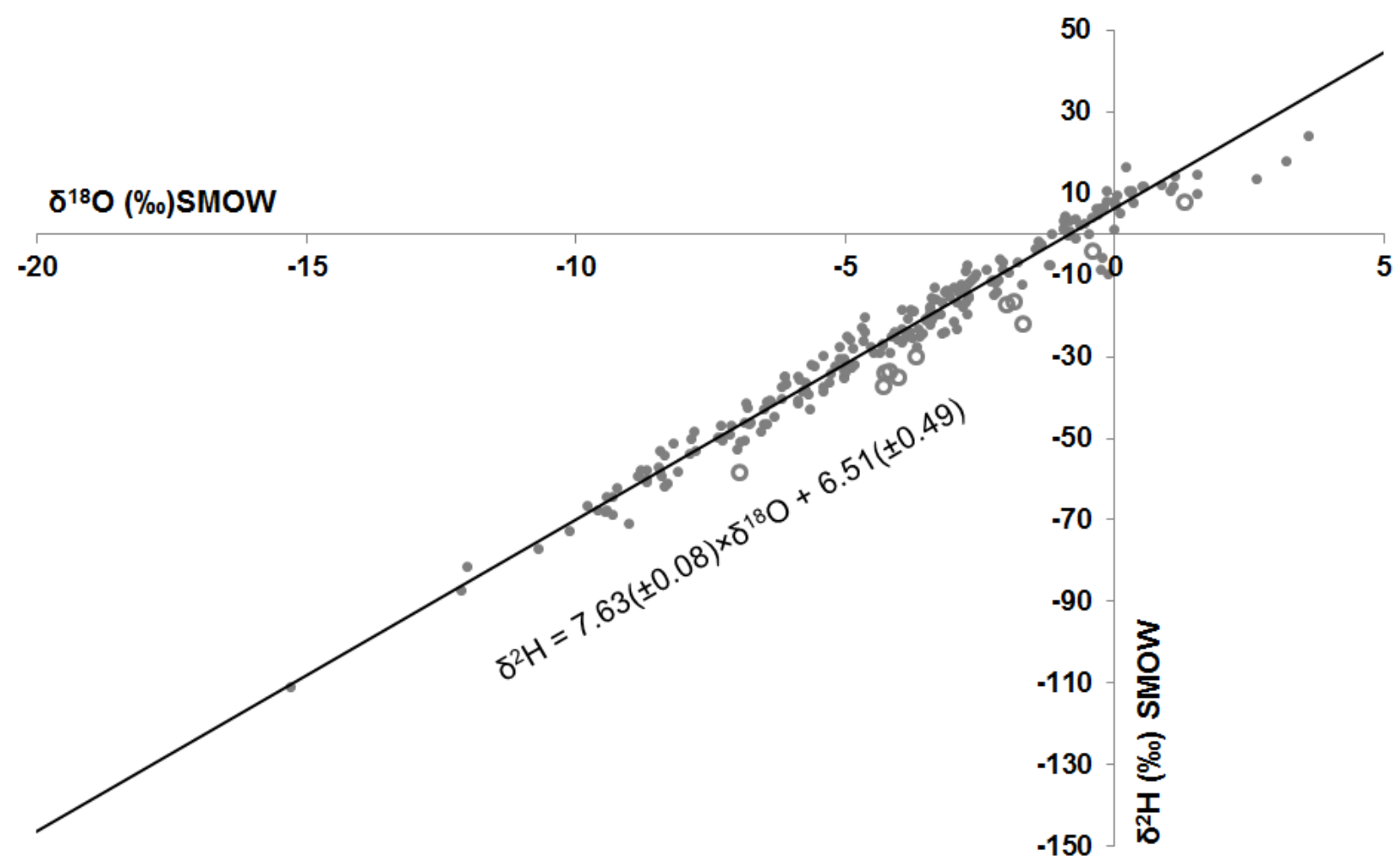

Figure 3. Distribution monthly-averaged $\delta^{2} \mathrm{H}-\delta^{8} \mathrm{O}$ for rainfall (grey dots) at two stations close the Pacific coast of central Panama, the former Howard Air Force Base and the University of Panama from 1968 to 2006 as a part of the IAEA-WMO Global Network of Isotopes in Precipitation program. The solid line is the precipitation-weighted local Meteoric Water Line (PW-LMWL) calculated from these data. Wet season samples with negative d-excess values (open circles) are probably modified by evaporation (e.g. due to a sampling failure) are shown just for completeness because had been disregarded in the LMWL determination.

As shown in Figure 3, the PW-LMWL for rainfall along the Pacific coast of central Panama determined by amount weighting is $\delta^{2} \mathrm{H}=7.63( \pm 0.08) \times \delta^{18} \mathrm{O}+6.51( \pm 0.49)$. There is only a slight difference between this rainfall $\delta^{2} \mathrm{H}-\delta^{8} \mathrm{O}$ relationship and the MWL of $\delta^{2} \mathrm{H}=7.40( \pm 0.07) \times \delta^{18} \mathrm{O}+$ 5.5( \pm 0.3$)$ determined using the standard approach [9]. It should be noted that Lachniet and Patterson [9] calculated an alternative MWL using weighted annual data. This approach took into account the differences in monthly precipitation totals and the resultant annual MWL exhibited a significantly higher intercept $\left(\delta^{2} \mathrm{H}=8.2 \times \delta^{18} \mathrm{O}+10.2\right)$ that is similar to the GMWL. Present results confirm the robustness of the MWL relationship derived from the monthly data set and reinforces the observation that the 'best-fit' line through the unweighted monthly data has lower slope and y-axis intercept values of $\sim 7.4$ and $\sim 5.5$, respectively [9], than the values of 8 and 10 for the general global MWL [33]. Our PW-LMWL applied a weighing scheme in which the evaporatively-enriched rains, typically small in amount, are given less influence in the calculation of the LMW than the standard unweighted approach [44]. This suggests that the 10 
Preprint of Kern, Z., Harmon, R.S., Fórizs, I. (2016) Stable isotope signatures of seasonal precipitation on the Pacific coast of central Panama. Isotopes in Environmental and Health Studies 52: 128-140. doi: 10.1080/10256016.2015.1016021

deviation from the global MWL observed for central Panama is not due to a secondary evaporation effect on raindrops falling during the dry season as previously inferred [9]. The lack of any systematic seasonal variability in d-excess (Fig.2c) also argues against an influence on the local MWL due to seasonal changes in moisture source.

\subsection{Spatial correlation of the water stable isotope signal of the precipitation at the Pacific coast of Panama}

Water $\mathrm{H}$ - and $\mathrm{O}$ - isotope signals for central Panama yield similar correlation patterns, in line with expectation due to their strong linear co-dependence. Spatial correlation analysis largely confirms the structure observed for $\delta^{18} \mathrm{O}$ values at the former Howard AFB site [10] and partially agrees with the modelling results [12]. Precipitation isotope variability is positively correlated with SSTs in the eastern tropical Pacific and negatively correlated with Caribbean SSTs (Fig. 4). However, the extended period of analysis, the more detailed partition of the rainy season, and consideration of the higher-resolution of $\delta^{2} \mathrm{H}$ record provide additional insights into controls on rainfall isotopic compositions along the Pacific coast of central Panama.

The H-isotope record exhibits a stronger co-variation to Caribbean SST variability during the early wet season than for other times of year. By contrast, O-isotope variations are linked more closely to Caribbean SSTs during the mid-summer and late-wet season. Detailed examination of the wet season isotopic record reveals that the negative correlation to the Caribbean-Atlantic SSTs is restricted only to the very beginning of the wet season in May-June with, as already noted, the mid-summer period characterized by a positive correlation to the east Pacific SSTs that is similar to the late wet season situation. The sharp termination along $\sim 20^{\circ} \mathrm{N}$ at the northern edge of the response field of $\delta^{2} \mathrm{H}$ over the tropical Atlantic reflects a link to large-scale atmospheric circulation [48] more specifically to the northern Hadley cell. As the ITCZ passes over the Panamanian isthmus and north/northeasterly airflow is displaced by a south/southwesterly flow (i.e. the Southern Trade Winds), the significant co-variation of precipitation stable isotope composition with SST disappears from the Caribbean-Atlantic domain in favour of control by the eastern Pacific. At this time, the field of significant correlation broadly covers the southern Hadley cell. The results are consistent with the Lagrangian moisture source identification, indicating that Southern Central America receives moisture that originates from the Pacific source region during summer and autumn [16]. Interesting to note the slight but meaningful shift of the core region of the correlation field from the midsummer period to the late wet season. The maximum correlation found between $\sim 5$ to 15 $\mathrm{N}$ latitudinal belt for the July-August, while shifted to the Equator (between $5 \mathrm{~S}$ to $5 \mathrm{~N}$ ) for the late wet season. This change can be logically link to the coinciding equatorward drift of the ITCZ and implies a southward displacement of the main distal moisture source region within the Eastern Pacific. A proximal moisture source region during the late wet season is also indicated 
Preprint of Kern, Z., Harmon, R.S., Fórizs, I. (2016) Stable isotope signatures of seasonal precipitation on the Pacific coast of central Panama. Isotopes in Environmental and Health Studies 52: 128-140. doi: 10.1080/10256016.2015.1016021

by the significant correlations obtained for the nearby off-shore region along the Pacific coast of the Isthmus (Fig. 4).
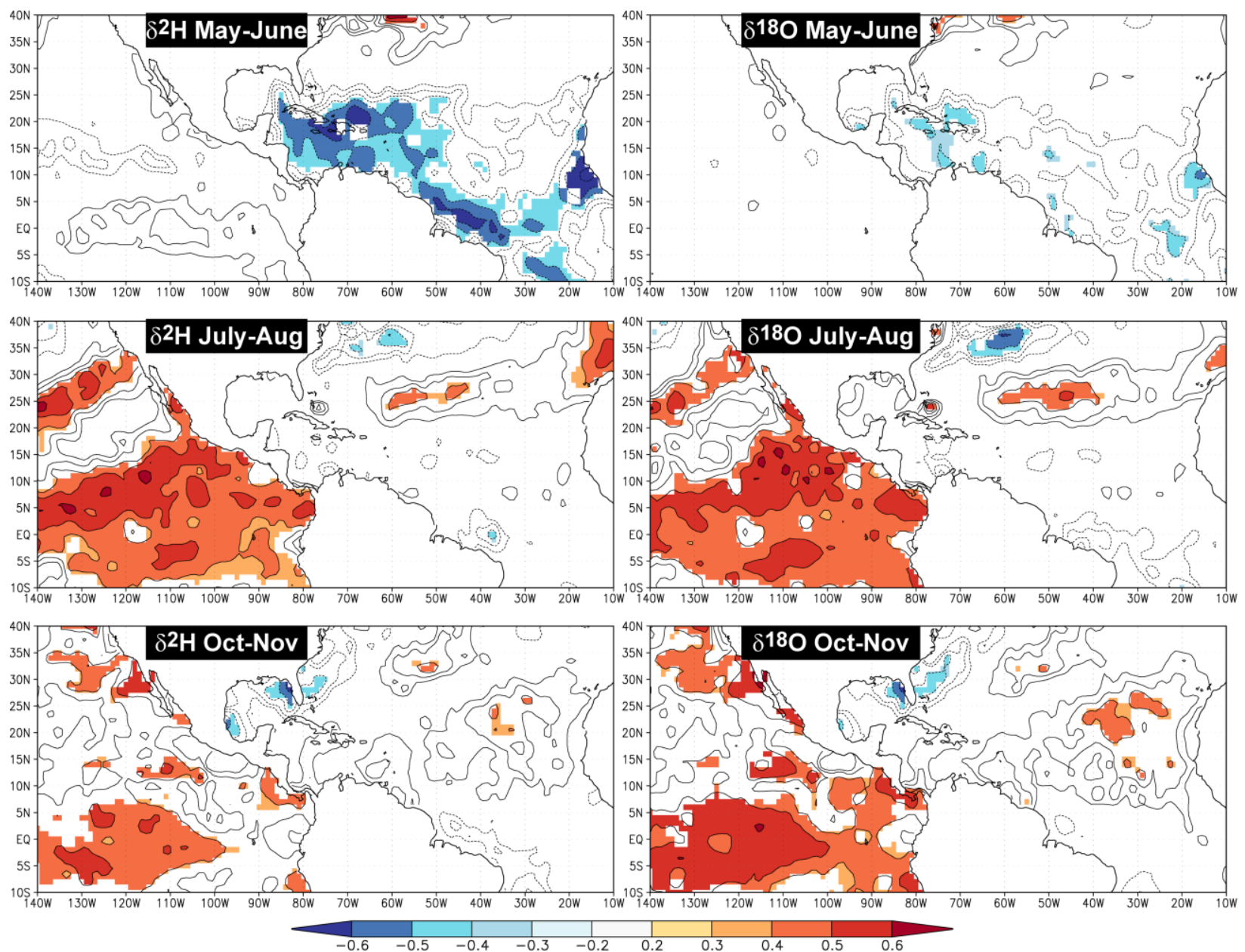

Figure 4. Maps of correlation computed between sea surface temperature and the stable isotope composition ( $\delta^{2} \mathrm{H}$ in left column and $\delta^{18} \mathrm{O}$ in right column) of precipitation at the Pacific coast of central Panama. May-June (first row), July-August (second row), and October-November (third row). Isoline spacing is $0.1 ; r>0(r<0)$ is indicated by full (dotted) lines. Coefficients significant at $\mathrm{p}=0.1$ level are highlighted.

In addition, these patterns raise a question about the different control mechanisms that influence the isotopic composition of precipitation in central Panama between the seasons. Earlier work has linked both negative Caribbean and positive Pacific correlations to the 'amount effect' [10]. However, our observation that the lowest isotopic ratios do not coincide temporally with the annual rainfall peak (Fig. 2) challenges this explanation.

The recent hypothesis by Kurita [49] suggests that stratiform rainfall associated with mesoscale convective systems (MCSs) is a key process in generating lower than expected isotope ratios in tropical precipitation. This idea posits that the majority of precipitation in a convectively active region/period falls from propagating synoptic-scale disturbances, each of 
Preprint of Kern, Z., Harmon, R.S., Fórizs, I. (2016) Stable isotope signatures of seasonal precipitation on the Pacific coast of central Panama. Isotopes in Environmental and Health Studies 52: 128-140. doi: 10.1080/10256016.2015.1016021

which consists of several MCSs. Thus, successive rainfall events from MCSs generate increased precipitation over a region that is characterized by heavy isotope depletion. Such a situation is a reasonable explanation for the low $\delta^{2} \mathrm{H}$ and $\delta^{18} \mathrm{O}$ values observed at the beginning of the wet season, when the Pacific ITCZ is located adjacent to the southern coast of Panama (Fig. 1). It has been shown that MCSs are influenced by the seasonal radiative cycle [50] and that the largest stratiform fractions occur over the oceanic ITCZs [51]. It has also been observed that convective available potential energy (CAPE) is generally high in the vicinity of broad, deep tropical MCSs [52] and that a high CAPE is necessary to sustain a broad convective system [53]. The early wet season is characterized by the highest CAPE values along the Pacific coast of Panama [19]. Warmer Caribbean SSTs produce a moisture-enriched Caribbean boundary layer and thus higher CAPE producing intensified advection of hydrometeors from the convective to stratiform regions of the MCS that enhances the stratiform precipitation rate. The strongest moist static instability has been found over the central Caribbean region, the warmest SST zone in the vicinity of Central America [19]. Caribbean SST is an important trigger for the stratiform rain fraction observed during May-June in central Panama. Hence, the anticorrelation of precipitation isotopic composition in coastal central Panama with Caribbean SST can be interpreted as a consequence of the stratiform rain fraction of the ITCZ associated rainfall belt.

By contrast, in a convectively inactive region/period, precipitation falls from local convection systems (e.g., isolated convective storms) so that locally evaporated moisture is the dominant source of boundary layer moisture and convective rainfall. This latter situation would then apply to the remainder of the wet season, when the organized ITCZ convective zone and it associated stratiform belt is located away from Panama (Fig. 1) and local/regional moisture convergence governed by the activities of the Caribbean and Colombian low-level jets. The observed positive isotopic-SST correlation pattern over the Pacific Ocean is in line with the expectation for moisture of Pacific origin and a single-step Rayleigh distillation process. In this case, the positive isotopic-SST correlation can be interpreted as the signal of evaporative surface temperature transferred into source moisture via the temperature dependent isotope fractionation factor.

\section{Conclusions}

This study presents a revised local 'Meteoric Water Line' of $\delta^{2} \mathrm{H}=7.63 \times \delta^{18} \mathrm{O}+6.51$ for the Pacific coast of central Panama based on an amount-weighted calculation approach. This methodology dampens the influence of small-quantity dry season rains that are prone to evaporative enrichment. Thus, it offers the potential for more insight into hydrometeorological process control than the standard, non-weighted approach.

The Pacific coast of Panama experiences a rainy season from late April to late November, and a dry season in December-April; two rainfall maxima occur in June and October, interrupted 
Preprint of Kern, Z., Harmon, R.S., Fórizs, I. (2016) Stable isotope signatures of seasonal precipitation on the Pacific coast of central Panama. Isotopes in Environmental and Health Studies 52: 128-140. doi: 10.1080/10256016.2015.1016021

by a relatively drier time. Each of these episodes is governed by a distinct dominant atmospheric circulation regime. After appropriately reducing the influence of dry season rainfall on the overall $\delta^{2} \mathrm{H}-\delta^{18} \mathrm{O}$ relationship for the Pacific coastal region of central Panama, the amountweighted mean isotopic values for the bi-monthly core period of the three characteristic stages of the wet season (i.e. early wet season maxima, late wet season maxima, and the intervening midsummer rainfall minima) were spatially correlated against SST fields of the tropical oceans. Results obtained reveal that the negative correlation of rainfall isotopic compositions to SSTs in the Caribbean Atlantic is restricted only to just the very beginning of the wet season (May-June) when the ITCZ and associated organized convective systems are proximal to the Pacific coast of Panama. The inverse relationship is attributed to the variable stratiform rain fraction [47]. By contrast, with the mid-summer period of reduced precipitation positively correlated to the pattern of eastern Pacific SSTs, in a manner similar to that of the late wet season when ITCZ is distant from the Pacific coast of Panama. This positive isotopic-SST correlation can be interpreted simply as the signal of evaporative surface temperature.

\section{Acknowledgements}

This work was supported by the Lendület program of the Hungarian Academy of Sciences under Grant LP2012-27/2012. Thanks to Markus Ziese (Deutscher Wetterdienst, Global Precipitation Climatology Centre) for information on accuracy of and uncertainty in GPCC rainfall estimates. This is contribution No.13 of the 2 ka Palæoclimatology Research Group.

\section{References}

[1] Coates AG, Jackson JBC, Collins LS, Cronin TM, Dowsett HJ, Bybell LM, Jung P, and Obando JA. Closure of the Isthmus of Panama: The near-shore marine record of Costa Rica and western Panama. Geol Soc Am Bull. 1992; 104:814-828.

[2] Keigwin, L.D. Isotopic paleoceanography of the Caribbean and east Pacific. Role of Panama uplift in Late Neogene time. Science. 1982; 217: 350-352.

[3] Haug G.H. and Tiedemann R. Effect of the formation of the Isthmus of Panama on Atlantic Ocean thermohaline circulation. Nature. 1998; 393: 673-676.

[4] Zaucker, F., Stocker, T.F., and Broecker, W.S. Atmospheric freshwater fluxes and their effect on the global thermohaline circulation. J. Geophys. Res. 1994; 99: 12443- 12457.

[5] Schmittner, A., Appenzeller, C., and Stocker, T.F. Enhanced Atlantic freshwater export during El Niño. Geophys. Res. Lett., 2000; 27:1163-1166.

[6] Schmittner A. and Clement, A.C. Sensitivity of the thermohaline circulation to tropical and high latitude freshwater forcing during the last glacial - interglacial cycle. Paleoceanography, 2002; 17 doi:10.1029/2000PA000591.

[7] Prange, M., Steph, S., Schulz, M. and Keigwin, L.D. Inferring moisture transport across Central America: Can modern analogs of climate variability help reconcile paleosalinity records? Quat.Sci. Rev. 2010, 29: 1317-1321. 
Preprint of Kern, Z., Harmon, R.S., Fórizs, I. (2016) Stable isotope signatures of seasonal precipitation on the Pacific coast of central Panama. Isotopes in Environmental and Health Studies 52: 128-140. doi: 10.1080/10256016.2015.1016021

[8] Lachniet, M.S., Patterson, W.P., Burns, S., Asmerom, Y., and Polyak, V. Caribbean and Pacific moisture sources on the Isthmus of Panama revealed from stalagmite and surface water $\delta^{18}$ O gradients. Geophys. Res. Lett. 2007; 34, L01708, doi:10.1029/2006GL028469

[9] Lachniet M.S. and Patterson, W.P. Use of correlation and multiple stepwise regression to evaluate the climatic controls on the stable isotope values of Panamanian surface waters. J. Hydrol. 2006; 324: 115- 140.

[10] Lachniet, M.S. Sea surface temperature control on the stable isotopic composition of rainfall in Panama. Geophys. Res. Lett. 2009, 36, L03701, doi:10.1029/2008GL036625.

[11] Dansgaard, W. Stable isotopes in precipitation. Tellus. 1964; 16: 436-368.

[12] Vuille, M., Bradley, R.S., Werner, M., Healy, R., and Keimig F. Modeling $\delta^{18} \mathrm{O}$ in precipitation over the tropical Americas. 1. Interannual variability and climatic controls. J. Geophys. Res. 2003; 108: 4174, doi:10.1029/2001JD002038.

[13] Kurita, N., Ichiyanagi, K., Matsumoto, J., Yamanaka, M.D., and Ohata, T. The relationship between the isotopic content of precipitation and the precipitation amount in tropical regions, J. Geochem. Explor. 2009; 102: 113-122.

[14] Sturm, C., Hoffmann, G., and Langmann, B. Simulation of the stable water isotopes in precipitation over South America: Comparing regional to global circulation models. J. Clim. 2007; 20: 3730-3750.

[15] NASA Global Change Mater Directory, AFCCC DATSAV2, http://gcmd.nasa.gov/records/GCMD_USAFETAC_SFFMG.html (accessed 2014.03.13).

[16] Durán-Quesada, A. M., L. Gimeno, J. A. Amador, and R. Nieto Moisture sources for Central America: Identification of moisture sources using a Lagrangian analysis technique, J. Geophys. Res. 2010; 115, D05103, doi:10.1029/2009JD012455.

[17] Poveda, G., Waylen, P.R., and Pulwarty, R.S. Annual and interannual variability of the present climate in northern South America and southern Mesoamerica. Palaeogeogr. Palaeoclimatol. Palaeoecol. 2006; 234: 3-27.

[18] Windsor, D.M., Climate and moisture variability in a tropical forest: Long-term records from Barro Colorado Island, Panamá. Smithsonian Contrib. Earth Sci. 1990; 29: 1-145.

[19] Karnauskas, K.B., Seager, R., Giannini, A., and Busalacchi, A.J. A simple mechanism for the climatological midsummer drought along the Pacific coast of Central America, Atmósfera [online]. 2013; 26: 261-281. ISSN 0187-6236.

[20] Poveda, G., and Mesa, O.J. On the existence of Lloro (the rainiest locality on Earth): enhanced ocean-atmosphere-land interaction by a low-level jet. Geophys. Res. Lett. 2000, 27: $1675-1678$.

[21] Estoque, M.A., Luque, J., Monteza, M.C., and Garcia, J. Effects of El Nino on Panama rainfall. Geofis. Int. 1985; 24: 355-381.

[22] Hastenrath, S. Climate Dynamics of the Tropics. Kluwer Academic Publishers, The Netherlands, 1991. 488 pp.

[23] DiMego, G.J., Bosart, L.F., and Endersen, G.W. An examination of the frequency and mean conditions surrounding frontal incursions into the Gulf of Mexico and Caribbean Sea. Monthly Weather Rev. 1976, 104: 709-718.

[24] Rand, A.S. and Rand, W.M. Variation in rainfall on Barro Colorado Island: in Leigh, E.G., Rand, S., and Windsor, D.M., eds., The Ecology of a Tropical Forest: Seasonal Rhythms and Long-Term Changes: Smithsonian Institution Press, Washington DC, 1982. p. 47-59.

[25] Cavelier, J., Solis, D., and Jaramillo, M.A. Fog interception in montane forest across the central cordillera of Panama. J. Tropical Ecol. 1996; 12: 357-369. 
Preprint of Kern, Z., Harmon, R.S., Fórizs, I. (2016) Stable isotope signatures of seasonal precipitation on the Pacific coast of central Panama. Isotopes in Environmental and Health Studies 52: 128-140. doi: 10.1080/10256016.2015.1016021

[26] Enfield, D.B. and Alfaro, E.J. The dependence of Caribbean rainfall on the interaction of the Tropical Atlantic and Pacific Oceans. J. Clim. 1999; 12: 2093-2103.

[27] Giannini, A., Kushnir, Y., and Cane, M.A. Interannual variability of Caribbean rainfall, ENSO, and the Atlantic Ocean. J. Clim. 2000; 13: 287-311.

[28] Shamir, E., Georgakakos, K.P., and Murphy, M.J. Frequency Analysis of the 7-8 December 2010 extreme precipitation in the Panama Canal Watershed. J. Hydrol. 2013; 480: 136-148.

[29] Murphy, M.J., Georgakakos, K.P., and Shamir, E. Climatological analysis of December rainfall in the Panama Canal Watershed. Int. J. Climatol. 2014; 34: 403-415.

[30] Alexander, M.A., Bladé, I., Newman, M., Lanzante, J.R., Lau, N.C., and Scott, J.D. The atmospheric bridge: The influence of ENSO teleconnections on air-sea interaction over the global oceans. J. Clim. 2002; 15: 2205-2231.

[31] Waylen, P. and Laporte, M.S. Flooding and the El Niño-Southern Oscillation phenomenon along the Pacific coast of Costa Rica. Hydrol. Proc. 1999; 13: 2623-2638.

[32] Benway, H.M., and Mix, A.C. Oxygen isotopes, upper-ocean salinity, and precipitation sources in the eastern tropical Pacific. Earth Planet. Sci. Lett. 2004; 224: 493-507.

[33] Craig, H. Isotopic variation in meteoric waters. Science. 1961, 133: 1702-1703.

[34] Gat, J.R. Oxygen and hydrogen isotopes in the hydrologic cycle. Ann. Rev. Earth Planet. Sci. 1996; 24: 225-262.

[35] IAEA/WMO, International Atomic Energy Agency/World Meteorological Organization (2014) Global Network of Isotopes in Precipitation. The GNIP Database. $<$ http://www.iaea.org/water>.

[36] Harmon, R.S., Kern, Z., Fórizs, I., Gardner, C., Lyons, W.B., and Ogden, F.L. Hydrometeorology and stable isotope geochemistry of Panama precipitation and rivers. Cent. European Geol. 2013; 56: 270-272.

[37] Coplen, T.B. Reporting of stable hydrogen, carbon and oxygen isotopic abundances. Pure App. Chem. 1994; 66: 273-276.

[38] NOAA NGDC 2-minute Gridded Global Relief Data (ETOPO2v2) 2006; http://www.ngdc.noaa.gov/mgg/fliers/06mgg01.html.

[39] Becker, A., Finger, P., Meyer-Christoffer, A., Rudolf, B., Schamm, K., Schneider, U., and Ziese, M. A description of the global land-surface precipitation data products of the Global Precipitation Climatology Centre with sample applications including centennial (trend) analysis from 1901-present. Earth Syst. Sci. Data, 2013; 5: 71-99.

[40] Ogden, F.L., Crouch, T.D., Stallard, R.F., and Hall, J.S. Effect of land cover and use on dryseason river runoff, runoff efficiency and peak storm runoff in the seasonal tropics of Central Panama. Water Resour. Res. 2013; DOI: 10.1002/2013WR013956.

[41] Meyer-Christoffer, A, Becker, A, Finger, P, Rudolf, B, Schneider, U., and Ziese, M. GPCC Climatology Version 2011 at $0.5^{\circ}$ : Monthly land-surface precipitation climatology for every month and the total year from rain-gauges built on GTS-based and historic data. 2011; DOI: 10.5676/DWD_GPCC/CLIM_M_V2011_050.

[42] Schneider, U., Becker, A., Finger, P., Meyer-Christoffer, A., Rudolf, B. and Ziese, M. GPCC Monitoring Product: Near Real-Time Monthly Land-Surface precipitation from RainGauges based on SYNOP and CLIMAT data. 2011; DOI: 10.5676/DWD_GPCC/MP_M_V4_100

[43] IAEA Statistical treatment of data on environmental isotopes in precipitation. Technical Report Series 331, IAEA Vienna, 1992. 781 pp. 
[44] Hughes C.E. and Crawford J. A new precipitation weighted method for determining the meteoric water line for hydrological applications demonstrated using Australian and global GNIP data. J, Hydrol. 2012; 464-465: 344-351.

[45] Rayner, N.A., Parker, D.E., Horton, E.B., Folland, C.K., Alexander, L.V., Rowell, D.P., Kent, E.C., and Kaplan, A. Global analyses of sea surface temperature, sea ice, and night marine air temperature since the late nineteenth century. J. Geophys. Res. 2003 108: No. D14, 4407 10.1029/2002JD002670.

[46] Trouet V. and Van Oldenborgh G.J. KNMI Climate Explorer: a web-based research tool for high-resolution paleoclimatology. Tree-Ring Res. 2013; 69: 3-13.

[47] Muñoz, E., Busalacchi, A. J., Nigam, S. and Ruiz-Barradas, A. Winter and summer structure of the Caribbean low-level jet. J. Clim. 2008; 21: 1260-1276.

[48] Feng, X., Faiia, A.M., and Posmentier, E.S. Seasonality of isotopes in precipitation: A global perspective. J. Geophys. Res., 2009; 114, D08116, doi:10.1029/2008JD011279.

[49] Kurita, N. Water isotopic variability in response to mesoscale convective system over the tropical ocean, J. Geophys. Res. Atmos. 2013; 118: 10,376-10,390, doi:10.1002/jgrd.50754.

[50] Laing, A.G. and Fritsch J.M. The global population of mesoscale convective complexes. Quart. J. Royal Meteorol. Soc. 1997; 123: 389-405.

[51] Schumacher, C. and Houze, R.A. Jr. Stratiform rain in the tropics as seen by the TRMM Precipitation Radar. J. Clim. 2003; 16: 1739-1756.

[52] Mapes, B.E. Gregarious tropical convection, J. Atmos. Sci. 1993; 50: 2026-2037.

[53]Houze, R.A., Jr. Mesoscale convective systems. Rev. Geophys. 2004; 42: RG4003. 